\title{
Article
}

Doi 10.5943/sif/4/1/31

\section{Carboxylesterase activity of filamentous soil fungi from a potato plantation in Mankayan, Benguet}

\author{
Poncian M, Beray BJW, Dadulla HCP and Hipol RM
}

Department of Biology, College of Science, University of the Philippines Baguio

Poncian M, Beray BJW, Dadulla HCP, Hipol RM 2019 - Carboxylesterase activity of filamentous soil fungi from a potato plantation in Mankayan, Benguet. Studies in Fungi 4(1), 292-303, Doi $10.5943 /$ sif/4/1/31

\begin{abstract}
In this study, filamentous fungi were isolated from a soil sample from a farm in Mankayan, Benguet. The isolates were tested for the presence of carboxylesterase enzyme as it would indicate the ability to breakdown pyrethroid pesticides such as Cypermethrin. A total of fourteen fungal isolates were characterized morphologically and were identified using the D1/D2 regions of 28S rDNA. All were identified to be members of the Ascomycetes. Seven of the isolates belong to the genus Fusarium, and two were identified to be Aspergillus heteromorphus and Penicillium sp. All fourteen isolates exhibited carboxylesterase activity. Isolates BDP3 and BDP10 exhibited the greatest carboxylesterase activity. These two isolates, both unidentified Ascomycetes, are promising species for mycoremediation specifically targeting pyrethroid pesticides.
\end{abstract}

Key words - Aspergillus heteromorphus - carboxylesterase - cypermethrin - pyrethroids

\section{Introduction}

The potential for bioremediation by fungi, also known as mycoremediation, is largely ignored. Singh (2006) says in his review paper that there is shortage of reports involving fungi in bioremediation because the biology and ecology of fungal metabolic processes are rarely examined. There is no shortage, however, in references that describe fungi as ubiquitous and highly adaptive organisms. These characteristics of fungi make mycoremediation technology applicable even in harsh conditions. One possible field of application can be found in modern farming, where the regular use of chemicals as pesticides and fertilizers is the norm. Such is the case for vegetable farms in Mankayan, Benguet. In this province, at least $54 \%$ of the labor force is engaged in vegetable and cut flower production. It is the leading economic activity of the province (Province of Benguet Official Website 2014). Mankayan specifically devotes 7,515 hectares (58\%) of its total land mass to agriculture, the key crops being highland vegetables (DILG-CAR 2014). Crops that are notably produced in Mankayan and other municipalities of the province include potatoes, carrots, broccoli, cauliflower, Chinese cabbage, and bell pepper. These vegetables are of temperate variety that are vulnerable to pest attacks such as borers and aphids. As such, farmers resort to pesticide use to drive away or kill these pests that decrease their yield and eventually their income (Piadozo 2008). 
Pesticides may be classified according to their mechanism of action. They disrupt the nervous system (insecticides), target the photosynthetic pathway (herbicides), and other biosynthetic reactions (fungicide, bactericide) (DeLorenzo et al. 2001). The use of these pesticides does increase the yield for the farmers. However, researches have demonstrated that pesticides can also be toxic to other non-target organisms, both terrestrial (Mahmood et al. 2016) and aquatic (Antwi \& Redd 2015). Many of the other organisms affected are beneficial, i.e. mycorrhiza affected by Benomyl fungicide (Channabasava et al. 2015). Deleterious effects of pesticides include reduced survival, growth and reproductive rate due to exposure to sub-lethal dosages (Ortiz-Hernandez et al. 2011).

Approximately $90 \%$ of pesticides do not even reach their target. Rather, they are dispersed in the air, soil and water (Ortiz-Hernandez et al. 2011) and thus, traces of it could be routinely detected especially in soil. Ecologically, pesticides disrupt the balance in the environment. To humans, adverse effects to health include poisoning, allergy, abdominal and chest pain, nausea, anorexia and fatigue and, in the most severe cases, fasciculation in large muscles of the extremities (World Health Organization 2005).

There are many synthetic compounds currently used as pesticides. They may be classified according to the target pest, the chemical structure of the compound used, or the degree or type of health hazard involved (Gevao et al. 2000). Among these include Gamma-hexachlorocyclohexane $(\gamma$-HCH) (Quintero et al. 2007), chlorpyrifos (Fang et al. 2008), and pyrethroids (Sakata et al. 1992). Synthetic pyrethroids are particularly interesting because it is a class of more than 1000 powerful, broad-spectrum insecticides used to control insect pests in agriculture, households, and stored products. (Mueller-Beilschmidt 1990). This insecticide is used worldwide in agriculture, forestry, horticulture, public health (i.e., hospitals, vector control), and residential pest control (e.g. landscape maintenance, structural pest control) (Werner \& Young 2017). But while these kill pests, it also poses a threat to the environment. Effects similar to those in insects have been observed in other organisms such as frogs that have ingested the insecticide. It is highly toxic to fish, bees, and water insects (United States Environmental Protection Agency 1989). In addition, its high persistence in the environment due to its hydrophobicity, stability in sunlight, and low volatility (amplifies its detrimental effects to the environment (Werner \& Young 2017). The half-life of cypermethrin in the soil can range from two to eight weeks (United States Environmental Protection Agency 1989).

Fungi are prime candidates for soil bioremediation as they are very ubiquitous in this habitat (Maqbool et al. 2016). Studies by Fang et al. (2008), Quintero et al. (2007), Silambarasan \& Abraham (2013), attest to the suitability of fungi to reduce the rate of soil pesticide pollution by discovering the activity of soil fungi in lowering the concentration of hexachlorocyclohexane and chlorpyrifos. The basidiomycete Trametes versicolor was also found to have successfully degraded imiprothrin, oxytetracycline, cypermethrin, and carbofuran (Mir-Tutusaus et al. 2014). Even the marine fungi Aspergillus sydowii and Penicillium decaturense were found to degrade methyl parathion (Alvarenga et al. 2014).

In a similar way, pyrethroids (including cypermethrin) are also vulnerable to enzymes that catalyze its cleavage (Leahey 1985, Sakata et al. 1992). The enzyme with this specific function is carboxylesterase (CES). This enzyme efficiently hydrolyzes a large number of endogenous and xenobiotic ester-containing compounds like the pyrethroids (Wang et al. 2009). In the study of Wheelock et al. (2006), they discovered that CES applied to water spiked with permethrin and bifenthrin was able to remove toxicity to Ceriodaphnia dubia by $1,000 \mathrm{ng} / \mathrm{L}$ and $600 \mathrm{ng} / \mathrm{L}$, respectively.

Fungi, together with the enzymes they produce (i.e carboxylesterase for pyrethroids), are very important in the bioremediation of environmental contaminants such as pesticides. They are the natural mode of decreasing the possible adverse effects of pesticide pollution. In this research, filamentous fungi exposed to cypermethrin (a pyrethroid) were identified and screened for the production of carboxylesterase. This will give us an idea of the level of resilience of environments chronically polluted with pesticides such as pyrethroids and the possible candidates for in-situ mycoremediation. 


\section{Materials \& Methods}

\section{Study Area}

The study area is located at Barangay Balili, Mankayan, Benguet (16 $51^{\prime} 38.96$ ” N 120 51 '15.07” E; elevation: 2315 masl) (Fig. 1). The farm is regularly planted with potato (Solanum tuberosum) in the area and that the plants are sprayed with a combination of the insecticide Cypermethrin and fungicide Mancozeb.

\section{Soil Sample Collection}

Soil collection was according to the methods of Harish et al. (2013). At a random area within the plantation, soil sample was obtained from the upper surface area of $0-15 \mathrm{~cm}$ soil layer of the garden then stored in an airtight polyethylene bag. The bag was kept at $4{ }^{\circ} \mathrm{C}$ in an ice box and was transported immediately to the laboratory of the University of the Philippines Baguio.

\section{Preparation of Pure Fungal Cultures}

The procedure for culturing fungi was adopted from Magnuson \& Lasure (2002). Ten percent soil suspension was prepared in a solution of $10 \mathrm{mM}$ potassium phosphate, $150 \mathrm{mM} \mathrm{NaCl}$, and $0.02 \%$ SDS (PBS-SDS), at pH 7. The suspension was agitated at $130 \mathrm{rpm}$ in $250 \mathrm{~mL}$ Erlenmeyer flasks for 20 minutes. Next, the soil particles were left to settle for 15 minutes before the liquid was decanted.

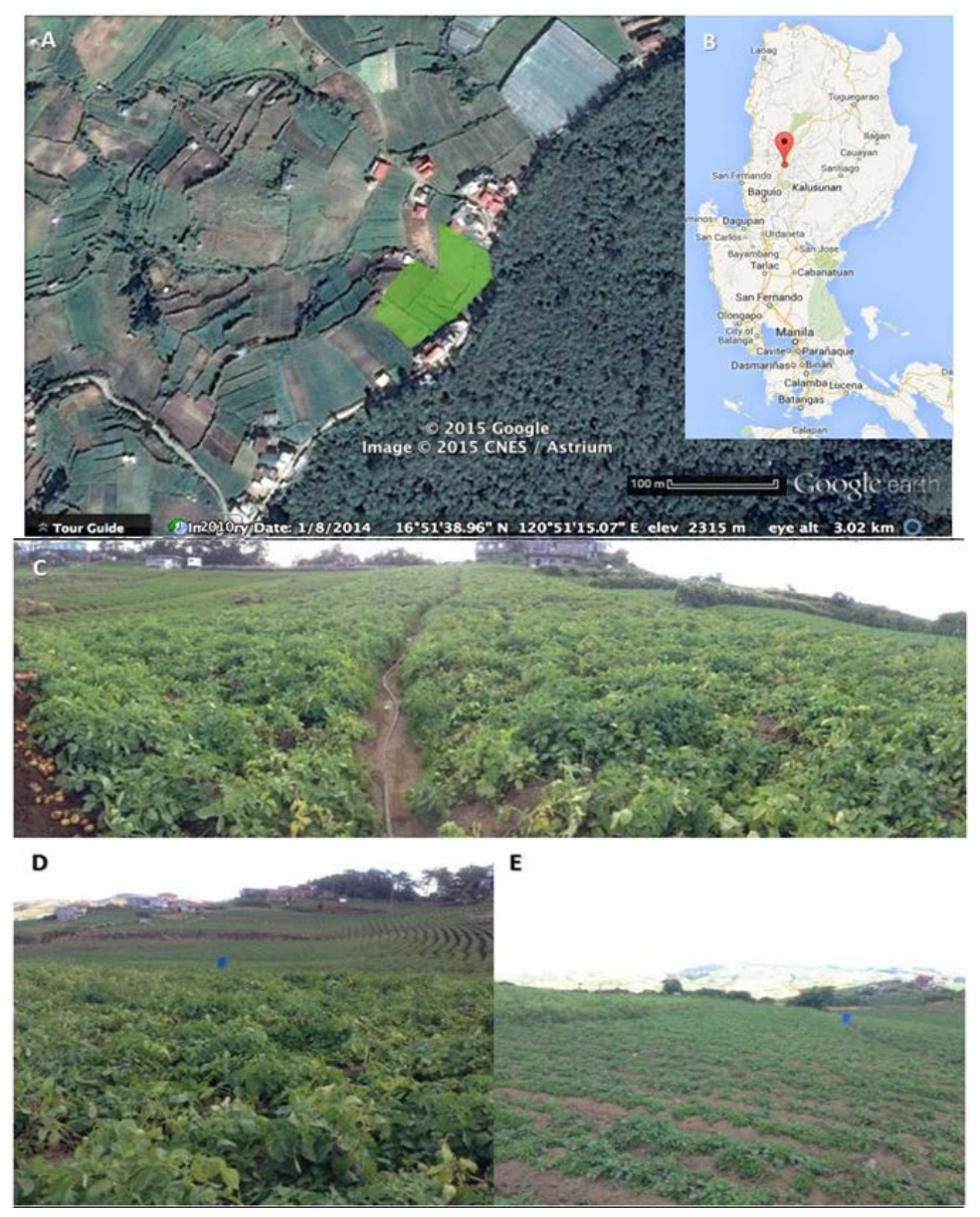

Fig. 1 - (A) A satellite image of the potato plantation. Image taken from Google Earth, 2015. (B) Map of Luzon Island, Philippines, showing the location of the plantation relative to Manila. Image taken from Google Maps, 2015. (C) The potato plantation, showing the cultivated area. Shading is noticeably absent. (D). Edges of the plantation populated by trees and houses. (E) An area within the plantation carved into a mountainside. 
The decantate was then serially diluted to up to 1:1000 in PBS. The diluted soil extracts were spread on plates of Potato Dextrose Agar (PDA) with chloramphenicol $(200 \mu \mathrm{g} / \mathrm{ml})$ and rose bengal $(200 \mu \mathrm{g} / \mathrm{ml})$, and were incubated at $30^{\circ} \mathrm{C}$, until colonies of at least $5 \mathrm{~mm}$ have grown.

Colonies in the plates that have unique morphological characteristics were taken as a separate isolate. Characteristics that were considered include any combination of the following: colony size, elevation, margin, surface texture, opacity, and color or pigmentation. Each isolate reinoculated in a PDA slant that contained chloramphenicol $(200 \mu \mathrm{g} / \mathrm{ml})$ and was incubated at $30^{\circ} \mathrm{C}$ for 7 days.

\section{Morphological Analysis of Filamentous Soil Fungi}

The morphological studies were conducted using macroscopic and microscopic analysis of fungal colonies.

Pure cultures of each filamentous soil fungi were sub-cultured in petri plates containing PDA media with chloramphenicol $(200 \mu \mathrm{g} / \mathrm{ml})$. They were incubated at $30^{\circ} \mathrm{C}$ for 5 days. The grown mycelia were studied under a Swift ${ }^{\circledR}$ SM100 Series Stereozoom microscope for the macroscopic analysis. The macroscopic features observed were size, elevation, margin, surface texture, opacity, and color.

Slide cultures were prepared for the microscopic analysis of the hyphae and spores. A block of PDA was transferred aseptically to the center of a sterile glass slide contained in a sterile petri plate. The four sides of the agar block were inoculated with spores or small portions of the mycelia. A sterile cover slip was laid over the agar block. The cultures were incubated for 3 days. Lactophenol methyl blue was used to stain the slide cultures.

Prepared slides were then pictured under an OPTIKA B-150 binocular electric microscope under high power objective.

\section{Molecular identification of Filamentous Soil Fungi}

DNA was extracted from the isolates using the Rapid Mini-Preparation of Fungal DNA for Polymerase Chain Reaction (PCR) by Liu et al. (2000).

PCR was conducted to amplify the D1/D2 regions of the large subunit of the 28S rDNA. Twenty five $\mu$ l of EmeraldAmp GT PCR Master Mix, $0.5 \mu$ l Reverse Primer (NL-1), $0.5 \mu \mathrm{l}$ Forward Primer (NL-4), and $23 \mu \mathrm{l}$ PCR grade water were added to PCR tubes containing $1 \mu \mathrm{l}$ of the DNA template obtained from DNA extraction of each pure culture. PCR tubes were run in LabNet ${ }^{\circledR}$ Multigene Gradient PCR machine for 3 hours. The products of PCR and the DNA were run through gel electrophoresis. Appearance of bands confirmed presence of DNA sequences. These were then sent to $1^{\text {st }}$ BASE, Singapore for polymerase chain reaction and DNA Sequencing of target rDNA.

DNA sequences were submitted to Basic Local Alignment Search Tool (BLAST) of the National Center for Biotechnology Information (NCBI) Genbank (blast.ncbi.nlm.nih.gov) for identification. Resulting DNA sequences showing $\geq 98 \%$ similarity were considered to belong to the same species (Arnold \& Lutzoni 2007) while sequences showing $\geq 95 \%$ similarity were considered to belong to the same genus. Moreover, sequences that showed $<95 \%$ similarity were considered unidentified taxon (Sánchez-Márquez et al. 2007).

\section{Carboxylesterase Activity Assay}

This test for carboxylesterase activity in fungi was carried out according to Avicor et al. (2012) where the enzyme acts on 1-naphthyl acetate and releases 1-naphthol with slight modifications. Three replicates were done for each isolate. Approximately, a 5 x $5 \mathrm{~mm}$ mycelia was aseptically cut from a plate culture and placed into a test tube containing $2.8 \mathrm{ml}$ of phosphate buffer solution (pH 7.0). A control set-up was also made that does not contain fungi. A $30 \mathrm{mM}$ 1-naphthyl acetate solution was prepared by dissolving Sigma ${ }^{\circledR}$ 1-naphthyl acetate in acetone. Next, a $100 \mu \mathrm{l}$ of the $30 \mathrm{mM}$ 1-naphthyl acetate solution was pipetted into the test tubes. Then, the mixture was incubated for 10 minutes in at $40^{\circ} \mathrm{C}$ in a water bath. 
After incubation, the reaction was stopped by adding $0.25 \mathrm{ml}$ of stop solution. The stop solution was adapted from Sree \& Varma (2015), which consisted of 3.4\% sodium dodecyl sulphate along with $0.8 \%$ Sigma-Aldrich ${ }^{\circledR}$ Fast Blue B salt, dissolved in Type 1 water. The Fast Blue B dye formed a complex with 1-naphthol that resulted in a change in absorbance. Prior to spectrophotometric analysis, the Shimadzu UVmini-1240 UV-Vis Spectrophotometer was tared using type 1 water as a blank. The absorbance of the resultant mixture was read immediately after adding the stop solution at $600 \mathrm{~nm}$. An increase in the absorbance of the sample against the control indicates carboxylesterase activity. The readings for each isolate were averaged. Carboxylesterase activity was then calculated using a calibration curve prepared from a standard solution of $36 \mu \mathrm{g} / \mathrm{ml}$ of Sigma-Aldrich ${ }^{\circledR}$ 1-naphthol and its 1:1 serial dilutions (Mohammed 2010). Resultant absorbance readings were plotted against the corresponding 1-naphthol standard curve.

\section{Statistical Analysis of Assay Results}

Statistical analysis was carried out using IBM SPSS version 21 using One-Way ANOVA $(\mathrm{p}<0.05)$. A Post hoc range test was done using Ryan-Einot-Gabriel-Welsch Q (R-E-G-W Q) post hoc criterion.

\section{Results}

\section{Filamentous Soil Fungi Identification}

Fourteen morphologically unique filamentous fungal isolates were taken from the soil dilution plates. The macroscopic morphological characteristics of the colonies were viewed under the Stereozoom microscope (Fig. 2). The following characteristics were observed in the macroscopic analysis: mycelia elevation, margin, surface, opacity, and color (Table 1). Convex, flat, nimbonate and raised were the types of elevation observed. One isolate exhibited the nimbonate type, two were convex, five were raised and six were flat. The most observed type of margin is filiform wherein 11 isolates exhibited it followed by the entire type which was exhibited by two fungal isolates. Only one had the lobate type. The glistening type of mycelia surface was the most occurring as seven isolates exhibited it. Four had a rough surface and three exhibited the dull type. In terms of opacity, all isolates were opaque.

On the other hand, the microscopic morphological characteristics of the hypha and spores of the isolates were observed under an electric microscope (Fig. 3). All of the fungal isolates exhibited a septate hyphae which indicated that they belong to Division Ascomycota. Three different types of spores were noted. These were the microconidia exhibited by five fungal isolates, the complex conidia exhibited by three, and the chlamydospore exhibited by three fungal isolates. Only BDP 7 exhibited two types of spores in its mycelia in the form of a microconidia and chlamydospore. The spores of the four isolates were not determined since no spores were formed in the cultures.

Eight of the fourteen isolates were identified using a query search in GenBank ${ }^{\circledR}$ using their DNA sequences from $1^{\text {st }}$ BASE. The identified species were Fusarium oxysporum, Fusarium sp. Aspergillus heteromorphus, and Penicillium sp. It was observed that the gene sequences of five isolates (BDP5, BDP6, BDP7, BDP11, and BDP14) correspond to one species match, $F$. oxysporum, but were found to be of different strains (Table 2). All other isolates were determined by the authors as unidentified as their maximum identity values were lower than $98 \%$.

\section{Carboxylesterase Activity Assay}

Absorbance values of each fungal preparation at $600 \mathrm{~nm}$ were extrapolated against a 1naphthol calibration curve $\left(\mathrm{y}=0.0416 \mathrm{x}+0.0569, \mathrm{R}^{2}=0.9937\right)$ in order to get the 1-naphthol equivalent concentration in each preparation. Post hoc analyses using R-G-E-W Q range test created homogeneous subsets among the isolates. It confirmed that the control has a significantly lower 1-naphthol equivalent concentration than all the isolates (Fig. 4). In addition, BDP 3 and BDP 10 were grouped into a single subset that the highest 1-naphthol equivalents than all other isolates. The others grouped together with intermediate 1-naphthol equivalents. 


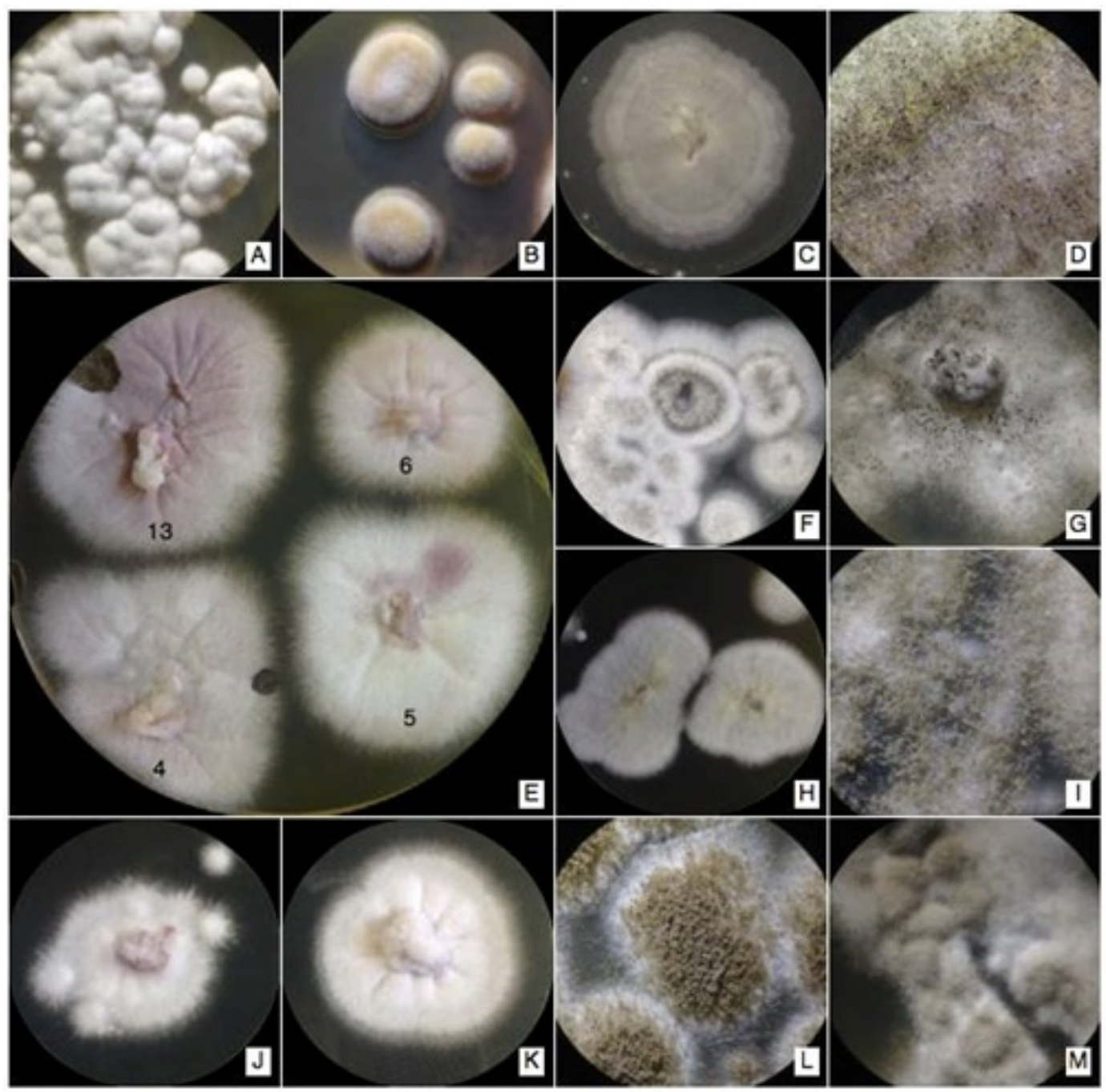

Fig. 2 - Filamentous fungal isolates from the soil of a potato plantation in Mankayan, Benguet. (A) BDP1. (B) BDP2. (C) BDP3 (D) BDP3. (E) Fusarium isolates. Clockwise from top left: Fusarium sp., F. oxysporum f. sp. lycopersici, F.oxysporum, Fusarium sp. (F) Aspergillus heteromorphus. (G) A. heteromorphus. (H) BDP9. (I) BDP9. (J) F. oxysporum strain FOCCB. (K) F. oxysporum. (L) BDP10. (M) Penicillium sp. A, B, D, G, I, L, and M were viewed under stereomicroscope.

Table 1 Morphological characteristics of filamentous fungi isolated from the soil sample taken from a potato plantation in Mankayan, Benguet.

\begin{tabular}{|c|c|c|c|c|c|c|c|c|}
\hline \multirow{2}{*}{ Isolate } & \multicolumn{6}{|c|}{ Macroscopic } & \multicolumn{2}{|c|}{ Microscopic } \\
\hline & Diameter & Elevation & Margin & Surface & Opacity & Color & Septa & Spore \\
\hline$\overline{\text { BDP1 }}$ & $4 \mathrm{~mm}$ & convex & entire & dull & opaque & white to brown & septate & NSF* \\
\hline BDP2 & $8 \mathrm{~mm}$ & convex & entire & dull & opaque & $\begin{array}{l}\text { brick red to } \\
\text { cream }\end{array}$ & septate & $\mathrm{NSF}^{*}$ \\
\hline BDP3 & $10 \mathrm{~mm}$ & flat & lobate & rough & opaque & $\begin{array}{l}\text { white hypha, } \\
\text { black spores }\end{array}$ & septate & chlamy-dospore \\
\hline BDP4 & $14 \mathrm{~mm}$ & flat & filiform & glistening & opaque & pink & septate & micro-conidia \\
\hline BDP5 & $7 \mathrm{~mm}$ & raised & filiform & glistening & opaque & white & septate & $\mathrm{NSF}^{*}$ \\
\hline BDP6 & $18 \mathrm{~mm}$ & raised & filiform & glistening & opaque & purplish white & septate & micro-conidia \\
\hline BDP7 & $1 \mathrm{~mm}$ & raised & filiform & glistening & opaque & pinkish white & septate & $\begin{array}{l}\text { micro-conidia, } \\
\text { chlamy- dospore }\end{array}$ \\
\hline BDP8 & $11 \mathrm{~mm}$ & flat & filiform & rough & opaque & $\begin{array}{l}\text { white hypha, da } \\
\text { brown spores }\end{array}$ & kseptate & complex conidia \\
\hline
\end{tabular}


Table 1 Continued.

\begin{tabular}{|c|c|c|c|c|c|c|c|c|}
\hline \multirow{2}{*}{ Isolate } & \multicolumn{6}{|c|}{ Macroscopic } & \multicolumn{2}{|c|}{ Microscopic } \\
\hline & Diameter & Elevation & Margin & Surface & Opacity & Color & Septa & Spore \\
\hline BDP9 & $8 \mathrm{~mm}$ & flat & filiform & Rough & opaque & $\begin{array}{l}\text { white hypha, } \\
\text { yellow green } \\
\text { spores }\end{array}$ & septate & chlamy-dospore \\
\hline BDP10 & $10 \mathrm{~mm}$ & flat & filiform & rough & opaque & $\begin{array}{l}\text { white hypha } \\
\text { green spores }\end{array}$ & septate & complex conidia \\
\hline BDP11 & $15 \mathrm{~mm}$ & raised & filiform & glistening & opaque & purplish white & septate & $\mathrm{NSF}^{*}$ \\
\hline BDP12 & $35 \mathrm{~mm}$ & nimbonate & filiform & dull & opaque & brown & septate & complex conidia \\
\hline BDP13 & $15 \mathrm{~mm}$ & raised & filiform & glistening & opaque & purplish white & septate & micro-conidia \\
\hline BDP14 & $10 \mathrm{~mm}$ & flat & filiform & glistening & opaque & white & septate & micro-conidia \\
\hline
\end{tabular}

*No spores found

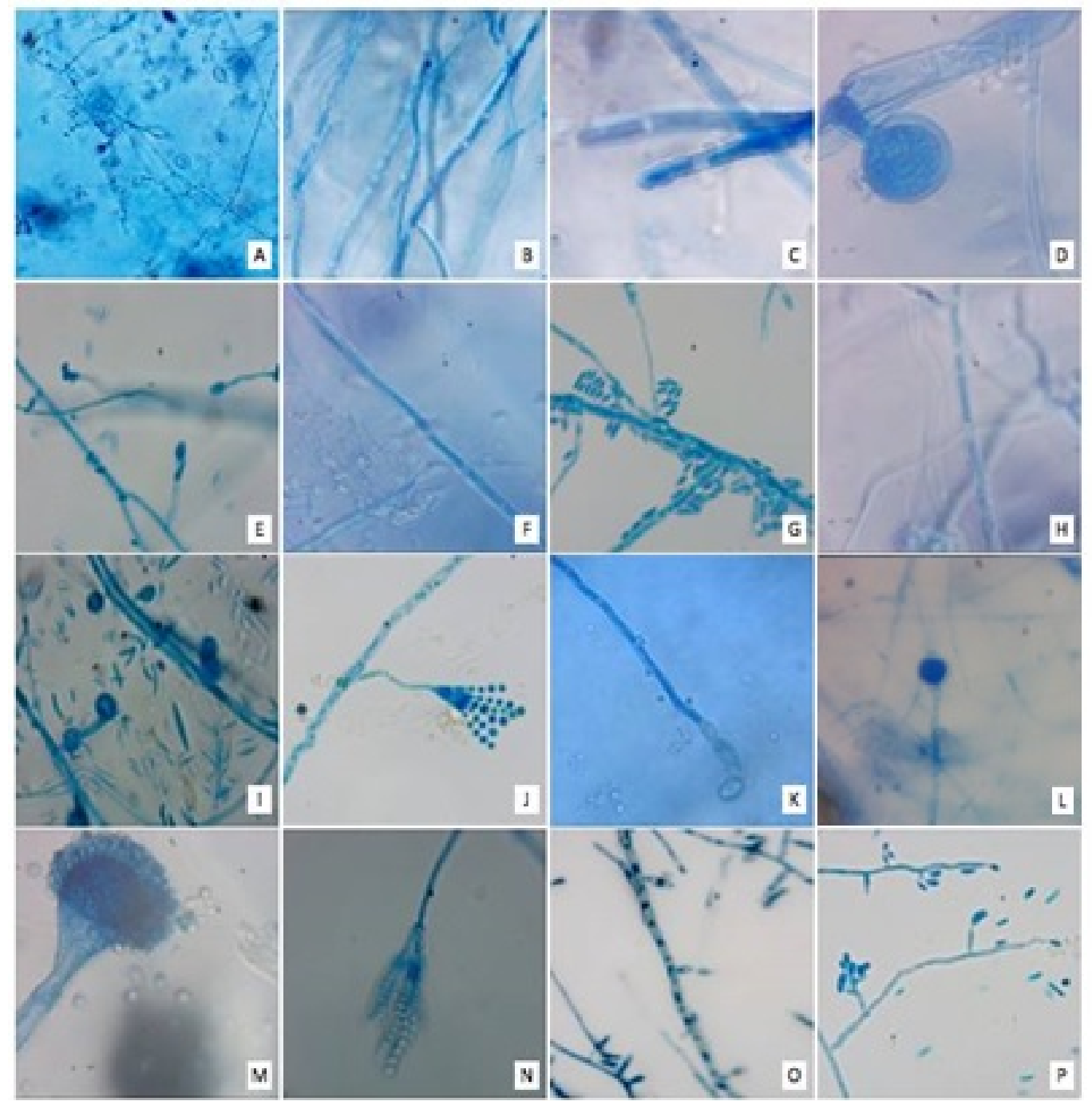

Fig. 3 - Filamentous fungal isolates from the soil of a potato plantation in Mankayan, Benguet. Stained with lactophenol methyl blue. Viewed under 400X magnification. (A) BDP1, branching hypha. (B) BDP2, hypha. (C) BDP3, budding hypha. (D) BDP4, chlamydospore. (E) Fusarium sp., hyphae. (F) F. oxysporum, hyphae. (G) F. oxysporum f. sp. lycopersici, microconidia. (H) F. oxysporum f. sp. lycopersici, hypha. (I) F. oxysporum strain FOCCB, microconidia. (J) Aspergillus heteromorphus strain SF-6390, complex conidia. (K) BDP9, hypha. (L) BDP9, chlamydospore. (M) BDP10, complex conidia. (N) Penicillium sp., complex conidia. (O). Fusarium sp., microconidia. (P) F. oxysporum, microconidia. 
Table 2 GenBank query search results and identification of the filamentous fungi isolated from soil taken from a potato plantation in Mankayan, Benguet.

\begin{tabular}{|c|c|c|c|c|c|}
\hline Isolate & Nearest Match & $\begin{array}{l}\text { Query } \\
\text { Cover }\end{array}$ & E Value & $\begin{array}{c}\text { Max } \\
\text { Identity }\end{array}$ & Identification \\
\hline BDP1 & $\begin{array}{l}\text { Penicillium gerundense } \\
\text { (EU427291.1) }\end{array}$ & $93 \%$ & $3 e-54$ & $70 \%$ & Unidentified Ascomycete \\
\hline BDP2 & $\begin{array}{l}\text { Aspergillus sylvaticus } \\
\text { (EF652448.1) }\end{array}$ & $92 \%$ & $4 e-148$ & $83 \%$ & Unidentified Ascomycete \\
\hline BDP3 & $\begin{array}{l}\text { Aspergillus deflectus } \\
\text { (EF652437.1) }\end{array}$ & $75 \%$ & $9 e-24$ & $68 \%$ & Unidentified Ascomycete \\
\hline BDP4 & $\begin{array}{l}\text { Fusarium cf. oxysporum OP } \\
\text { 12.d(KP017399.1) }\end{array}$ & $97 \%$ & 0.0 & $99 \%$ & Fusarium sp. \\
\hline BDP5 & $\begin{array}{l}\text { Fusarium oxysporum } \\
\text { (EF363781.1) }\end{array}$ & $97 \%$ & 0.0 & $99 \%$ & Fusarium oxysporum \\
\hline BDP6 & $\begin{array}{l}\text { Fusarium oxysporum } f \text {. sp. } \\
\text { lycopersici (EU214564.1) }\end{array}$ & $91 \%$ & 0.0 & $99 \%$ & $\begin{array}{l}\text { Fusarium oxysporum } f . \text { sp. } \\
\text { lycopersici }\end{array}$ \\
\hline BDP7 & $\begin{array}{l}\text { Fusarium oxysporum } \\
\text { (EF363781.1) }\end{array}$ & $97 \%$ & 0.0 & $98 \%$ & Fusarium oxysporum \\
\hline BDP8 & $\begin{array}{l}\text { Aspergillus heteromorphus strain } \\
\text { SF-6390 (KM434330.1) }\end{array}$ & $96 \%$ & 0.0 & $99 \%$ & $\begin{array}{l}\text { Aspergillus heteromorphus strain } \\
\text { SF-6390 }\end{array}$ \\
\hline BDP9 & $\begin{array}{l}\text { Fusarium oxysporum } \\
\text { (EF363781.1) }\end{array}$ & $96 \%$ & 0.0 & $87 \%$ & Unidentified Ascomycete \\
\hline BDP10 & $\begin{array}{l}\text { Penicillium janthinellum } \\
\text { (HM469429.1) }\end{array}$ & $89 \%$ & $1 \mathrm{e}-129$ & $82 \%$ & Unidentified Ascomycete \\
\hline BDP11 & $\begin{array}{l}\text { Fusarium oxysporum f. sp. } \\
\text { lycopersici (EU214564.1) }\end{array}$ & $91 \%$ & 0.0 & $99 \%$ & $\begin{array}{l}\text { Fusarium oxysporum } f . \text { sp. } \\
\text { lycopersici }\end{array}$ \\
\hline BDP12 & Penicillium sp. (GQ169751.1) & $95 \%$ & 0.0 & $98 \%$ & Penicillium sp. \\
\hline BDP13 & $\begin{array}{l}\text { Fusarium oxysporum } \\
\text { (KJ126550.1) }\end{array}$ & $95 \%$ & 0.0 & $97 \%$ & Fusarium sp. \\
\hline BDP14 & $\begin{array}{l}\text { Fusarium oxysporum } \\
\text { (EF363781.1) }\end{array}$ & $97 \%$ & 0.0 & $99 \%$ & Fusarium oxysporum \\
\hline
\end{tabular}

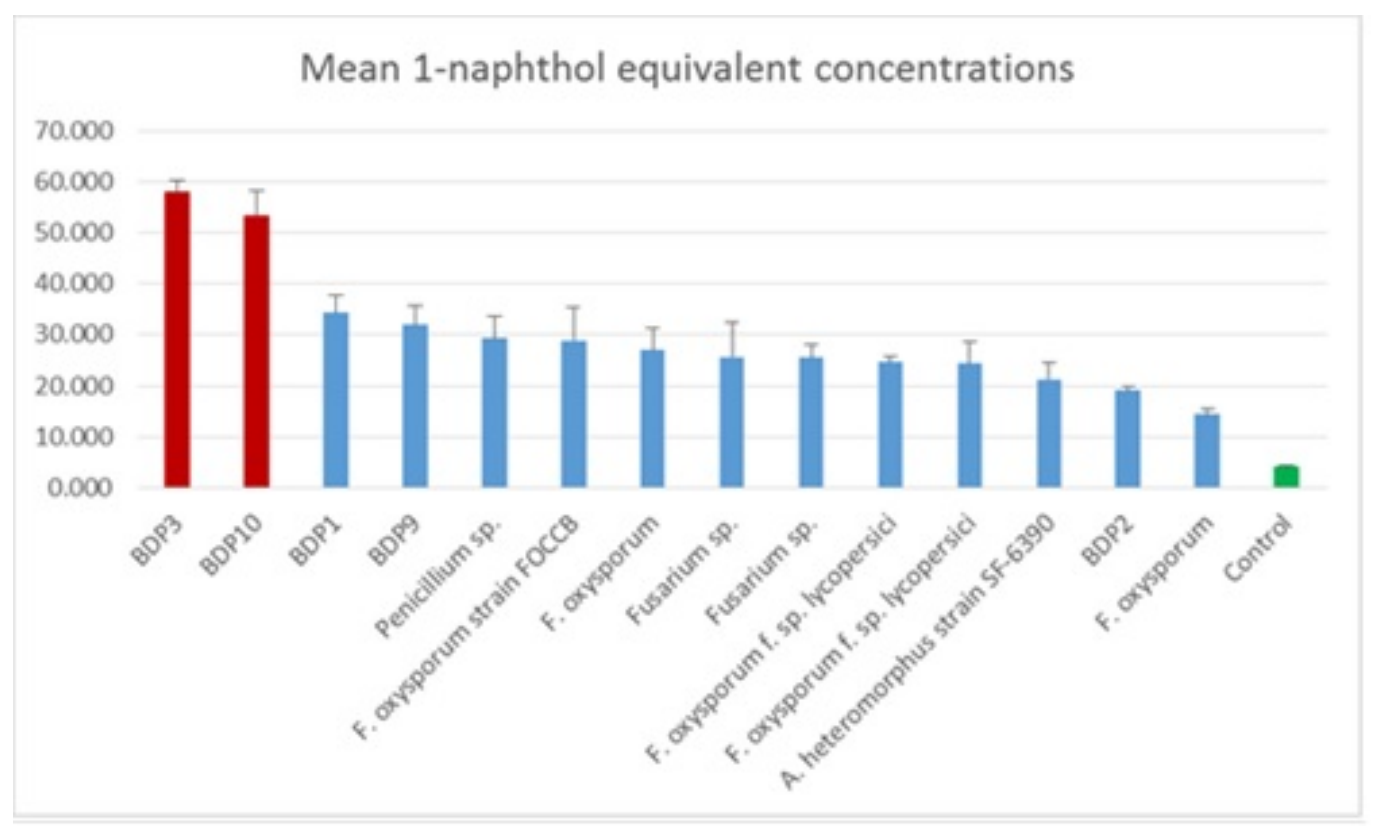

Fig. 4 - Mean concentration of 1-naphthol equivalent in the assay preparations for each fungal isolate. Means were grouped into subsets at $p=0.05$ using the R-G-E-W Q post hoc criterion. All isolates exhibit significantly higher carboxylesterase activity than the control. Isolates BDP3 and BDP10 were separated into a single subset that exhibited the highest carboxylesterase activity. 


\section{Discussion}

Fourteen isolates with unique morphological characteristics were collected from a soil suspension of the soil collected in Mankayan, Benguet. All of the isolates were sequenced and identified to be members of the Ascomycetes. This is expected because of the wide distribution of this group of fungi.

There seems to be low diversity among the isolates. Despite having exhibited differences in their morphology, especially in their color, seven of the isolates were identified to be Fusarium, five of which were identified at species level as Fusarium oxysporum. This species belongs to Class Sordariomycetes. The two other isolates identified using sequencing, Aspergillus heteromorphus and Penicillium sp., are closely related species (Samson et al. 2014). Both of them belong to Class Eurotiomycetes.

Fusarium is a ubiquitous species (Saika \& Kadoo 2010). They are well represented in any type of soil worldwide (Burgess 1981). The varying morphologies of the fungi may be due to them belonging to different strains despite them being similar species. The occurrence of $F$. oxysporum species in the isolates might be due to the abundance of host plants (potatoes) in the plantation from which they were isolated. The said species are known pathogens of plants regardless of their strains. In the study of Manici \& Cerato (1994) and Bayona et al. (2011), F. oxysporum isolates from infected tubers caused dry rot on inoculated tubers and infected the vascular tissues through roots and leaves.

Species belonging to the genus Aspergillus and Penicillium are ubiquitous soil inhabitants (Keller \& Bidochka 1998). The isolation of Penicillium sp. and Aspergillus heteromorphus from the plantation suggests that the fungal species play a role play a role in-situ. In the research conducted by Salami \& Popoola (2007), they isolated a Penicillium species in a diseased potato associated with post-harvest rot. Some Penicillium spp. isolates from the soil therefore could either be parasitic or saprophytic. On the other hand, no literature exists that indicate that A. heteromorphus is pathogenic to plants. Research journals instead indicate that they are capable of producing laccases (Singh et al. 2010) and cellulases (Singh et al. 2009) to degrade organic biomass. Hence, suggesting that the fungal isolate is saprophytic.

Results from the 1-napthol assay test indicate that all were able to degrade cypermethrin thus indicating carboxylesterase activity. This ability may be attributed to their chronic exposure to pyrethroids in-situ (Afify et al. 2013). Considering that the isolates were extracted from soil where the pyrethroid chemical - cypermethrin, was regularly applied, the isolates may have already adapted to such conditions. Thus it is possible that the pesticides applied in the garden are sources of carbon and nitrogen upon degradation by the isolates (Ellegaard-Jensen 2012).

Indication of carboxylesterase activity would imply that all have the potential to degrade pyrethroids such as cypermethrin and organophosphate pesticides that contain xenobiotic ester compounds in-situ (Wang et al. 2009). It is, however, important to consider the ecological roles of these fungi in order to be considered as viable candidates for mycoremediation. Fusarium, being known parasites, cannot be considered despite exhibiting carboxylesterase activity because these fungi may infect crops and reduce yield as it degrades the pesticide residues. The promising candidates for use in mycoremediation are isolates BDP3 and BDP10. Both are unidentified species but are more likely to be related to Aspergillus or Penicillium based on their morphology and on their close homology based on their D1/D2 sequence. Post hoc analysis results show that these isolates have exhibited the highest carboxylesterase activity among all isolates. The result suggests that the two isolates are more efficient at producing the carboxylesterase enzyme. Results therefore suggest that these would perform best at degrading cypermethrin and other pyrethroids and thus are prime candidates for mycoremediation of pyrethroid pollution in-situ.

\section{Conclusion}

A total of 14 isolates were isolated from the soil sample collected from a potato plantation in Mankayan, Benguet. Nine isolates were identified using morphological analysis and sequencing of the D1/D2 regions of the 28S rDNA. Of these nine isolates, seven belong to the genus Fusarium, 
five of which were identified to be $F$. oxysporum. The other two isolates were identified to be Aspergillus heteromorphus and Penicillium sp. In the 1-naphthol assay, it was found out that all of the isolates exhibited carboxylesterase activity. Post hoc analysis of the results showed that two unidentified Ascomycetes - BDP3 and BDP10, exhibited the greatest carboxylesterase activity. These two isolates are promising species for mycoremediation, specifically targeting pyrethroid pesticides.

\section{Acknowledgements}

The authors would like to acknowledge the support of the Department of Biology, College of Science, University of the Philippines Baguio for the conduct of this study.

\section{References}

Afify A, Abo-El-Seoud M, Ibrahim G, Kassem B. 2013 - Stimulating of Biodegradation of Oxamyl Pesticide by Low Dose Gamma Irradiated Fungi. Journal of Plant Pathology \& Microbiology 4(9), 1-5.

Alvarenga N, Birolli WG, Seleghim MH, Porto AL. 2014 - Biodegradation of methyl parathion by whole cells of marine-derived fungi Aspergillus sydowii and Penicillium decaturense. Chemosphere 117, 47-52.

Antwi FB, Reddy GV. 2015 - Toxicological effects of pyrethroids on non-target aquatic insects. Environmental toxicology and pharmacology 40(3), 915-923.

Arnold AE, Lutzoni F. 2007 - Diversity and host range of foliar fungal endophytes: are tropical leaves biodiversity hotspots? Ecology 88,541-549.

Avicor S, Owusu E, Eziah V, Wajidi M. 2012 - Carboxylesterase Activity of Bemisia tabaci (Hemiptera: Aleyrodidae): Subcellular Distribution, Temperature and pH Effects. Bulletin of Environment, Pharmacology and Life Science, 2 (1), 37-40.

Bayona L, Grajales A, Cárdenas M. 2011 - Isolation and characterization of two strains of Fusarium oxysporum causing potato dry rot in Solanum tuberosum in Colombia. Rev Iberoam Micologia 28(4), 166-172.

Burgess RW. 1981 - General ecology of the Fusaria. In Nelson, P.E., Tousson, T.A., Cook Rh. (Eds) Fusarium: diseases, biology and taxonomy. Pennsylvania: Pennsylvania State University Press. pp. 225-235

Channabasava A, Lakshman HC, Jorquera MA. 2015 - Effect of fungicides on association of arbuscular mycorrhiza fungus Rhizophagus fasciculatus and growth of Proso millet (Panicum miliaceum L. Journal of soil science and plant nutrition 15(1), 35-45.

DeLorenzo ME, Scott GI, Ross PE. 2001 - Toxicity of pesticides to aquatic microorganisms: a review. Environmental Toxicology and Chemistry: An International Journal 20(1), 84-98.

DILG-CAR 2014 - Department of Interior and Local Government - Cordillera Administrative Region. Municipality of Mankayan, Benguet. Retrieved November 6, 2014 from http://www.dilgcar.com/index.php/lgu/car-profile/benguet/mankayan

Ellegaard-Jensen L. 2012 - Fungal degradation of pesticides - construction of microbial consortia for bioremediation. (PhD Thesis). Retrieved October 4, 2014 from www2.bio.uk.dk/bibliotek/phd/Lea\%Ellegaard-Jensen.pdf

Fang H, Xiang YQ, Hao YJ, Chu XQ et al. 2008 - Fungal degradation of chlorpyrifos by Verticillium sp. DSP in pure cultures and its use in bioremediation of contaminated soil and pakchoi. International Biodeterioration \& Biodegradation 61(4), 294-303.

Gevao B, Semple KT, Jones KC. 2000 - Bound pesticide residues in soils: a review. Environmental Pollution 108(1), 3-14.

Harish R, Supreeth M, Chauhan JB. 2013 - Biodegradation of Organophosphate Pesticide by Soil Fungi. Advanced Bio Tech, 12(9).

Keller L, Bidochka MJ. 1998 - Habitat and temporal differences among soil microfungal assemblages in Ontario. Canadian Journal of Botany 76(10), 1798-1805. 
Leahey JP. 1985 - The Pyrethroid Insecticides. London: Taylor and Francis.

Liu D, Coloe S, Baird R, Pedersen J. 2000 - Rapid Mini-Preparation of Fungal DNA for PCR. Journal of Clinical Microbiology 38(1), 471.

Magnuson JK, Lasure LL. 2002 - Fungal Diversity in Soils as Assessed by Direct Culture and Molecular Techniques. In $102^{\text {nd }}$ General Meeting of the American Society for Microbiology, Salt Lake City. pp. 19-23.

Mahmood I, Imadi SR, Shazadi K, Gul A, Hakeem KR. 2016 - Effects of pesticides on environment. In Plant, soil and microbes (pp. 253-269). Springer, Cham.

Manici LM, Cerato C. 1994 - Pathogenicity ofFusarium oxysporum f. sp. tuberosi isolates from tubers and potato plants. Potato Research 37(2), 129-134.

Maqbool Z, Hussain S, Imran M, Mahmood F et al. 2016 - Perspectives of using fungi as bioresource for bioremediation of pesticides in the environment: a critical review. Environmental Science and Pollution Research 23(17), 16904-16925.

Mir-Tutusaus JA, Masís-Mora M, Corcellas C, Eljarrat E et al. 2014 - Degradation of selected agrochemicals by the white rot fungus Trametes versicolor. Science of the total environment 500, 235-242.

Mohammed DH. 2010 - Spectrophotometric determination of 1-naphthol via charge transfer complex formation. National Journal of Chemistry 38, 201-210.

Mueller-Beilschmidt D. 1990 - Toxicology and environmental fate of synthetic pyrethroids. Journal of Pesticide Reform 10(3), 32-37.

Ortiz-Hernandez L, Sanchez-Salinas E, Godinez M, Gonzales E, Ursino E. 2011 - Pesticides in the Environment: Impacts and its Biodegradation as a Strategy for Residues Treatment. En: Pesticides-Formulations, Fate. (M. Stoytcheva, Ed.) Intech. Croatia, 551-574.

Piadozo M. 2008 - Vegetable Production and Marketing in Benguet and Laguna: Implications for Sustainability. Agricultural \& Applied Economics Research Bulletin 2(3-4), 4.

Province of Benguet Official Website. 2014 - Retrieved October 9, 2014 from http://www.benguet.gov.ph/index.php?option=com_content\&view=article\&id=316:fastfacts\&catid=73:general

Quintero JC, Lu-Chau TA, Moreira MT, Feijoo G, Lema JM. 2007 - Bioremediation of HCH present in soil by the white-rot fungus Bjerkandera adusta in a slurry batch bioreactor. International Biodeterioration \& Biodegradation, 60(4), 319-326.

Saika R, Kadoo N. 2010 - Molecular Detection and Identification of Fusarium oxysporum. In Gherbawy, Y., Viogt, K. (Eds.) Molecular Identification of Fungi.

Sakata S, Mikami N, Yamada H. 1992 - Degradation of Pyrethroid Optical Isomers by Soil Microorganisms. Journal of Pesticide Science 17, 181-189.

Salami A, Popoola O. 2007 - Thermal control of some post-harvest rot pathogens of irish potato (Solanum tuberosum L.). Journal of Agricultural Sciences 52(1), 17-31.

Samson RA, Houbraken J, Visagie CM, Meijer M et al. 2014 - A taxonomic and phylogenetic revision of Penicillium section Aspergilloides. Studies in Mycology 78, 373-451.

Sánchez-Márquez S, Bills GF, Zabalgogeazcoa I. 2007 - The endophytic mycobiota of the grass Dactylis glomerata. Fungal Diversity 27, 171-195.

Silambarasan S, Abraham J. 2013 - Ecofriendly method for bioremediation of chlorpyrifos from agricultural soil by novel fungus Aspergillus terreus JAS1. Water, Air, \& Soil Pollution 224(1), 1369.

Singh A, Bajar S, Bishnoi NR, Singh N. 2010 - Laccase production by Aspergillus heteromorphus using distillery spent wash and lignocellulosic biomass. Journal of Hazardous Materials 176(1-3), 1079-1082.

Singh A, Singh N, Narsi B. 2009 - Production of Cellulases by Aspergillus Heteromorphus from Wheat Straw under Submerged Fermentation. World Academy of Science, Engineering and Technology 3.

Singh H. 2006 - Mycoremediation: Fungal bioremediation. New Jersey: John Wiley \& Sons Inc. 
Sree KS, Varma A. 2015 - Biocontrol of Lepidopteran Pests: Use of Soil Microbes and Their Metabolites. Berlin, Germany: Springer-Verlag GmbH.

United States Environmental Protection Agency. 1989 - Cypermethrin [National Pesticide Telecommunications Center (NPTC) fact sheets]. Retrieved April 20, 2015 from http://npic.orst.edu/factsheets/cypermethrin.pdf

Wang B, Guo P, Hang B, Li L et al. 2009 - Cloning of a Novel Pyrethroid-Hydrolyzing Carboxylesterase Gene from Sphingobium sp. Strain JZ-1 and Characterization of the Gene Product. Applied Environmental Microbiology 75(17), 5496-5500.

Werner I, Young T. 2017 - Pyrethroid insecticides-exposure and impacts in the aquatic environment. Encyclopedia of the Anthropocene.

Wheelock CE, Miller JL, Miller MJ, Phillips BM et al. 2006 - Use of carboxylesterase activity to remove pyrethroid-associated toxicity to Ceriodaphnia dubia and Hyalella azteca in toxicity identification evaluations. Environmental Toxicology and Chemistry: An International Journal 25(4), 973-984. 